\title{
Pneumatologiczna wiarygodność Kościoła
}

\section{The Pneumatological Credibility of the Church}

\author{
JACENTY MASTEJ \\ Katolicki Uniwersytet Lubelski Jana Pawła II \\ jmastej@kul.lublin.pl, ORCID: 0000-0001-7888-4078
}

\begin{abstract}
Streszczenie: Niniejsze opracowanie ukazuje pneumatologiczną wiarygodność Kościoła. Cel ten został zrealizowany w trzech punktach. Najpierw zaprezentowano wydarzenie Pięćdziesiątnicy jako eklezjogenetyczny dar Ducha Świętego. Następnie ukazano pneumatologiczną ikoniczność Kościoła. W trzecim punkcie wyeksplikowano znaki pneumatologicznej wiarygodności Eklezji. Holistyczna prezentacja obecności i działania Ducha Świętego w Kościele - zarówno w jego genezie, jak również w permanentnym urzeczywistnianiu się w historii - stanowi podstawę do wykazania jego absolutnej wyjątkowości, co jest możliwe przy równoczesnym udziale ratio i fides. Pneumatologiczna wiarygodność Kościoła jest ściśle powiązana z innymi argumentami budowanymi w ramach teologii fundamentalnej, np. skrypturystycznym, rezurekcjonistyczny, agapetologicznym, martyrologicznym, prakseologicznym, sperancyjnym, werytatywnym czy ze świętości. W argumentach tych trzeba jeszcze mocniej uwyraźniać aspekt pneumatologiczny.
\end{abstract}

Słowa kluczowe: Duch Święty; Jezus Chrystus; Kościół; wiarygodność Kościoła

Abstract: The aim of this paper is to demonstrate the pneumatological credibility of the Church, a goal achieved via three lines of analysis. First, the event of Pentecost is presented as an ecclesio-genetic gift of the Holy Spirit. Then the pneumatological iconicity of the Church is shown. In the third point, the essential signs constituting the pneumatological credibility of Ecclesia are explained. The holistic presentation of the presence and action of the Holy Spirit in the Church - both in its genesis and in its permanent realisation in history - is the basis for demonstrating its absolute uniqueness, which is possible with the simultaneous participation of ratio and fides. The pneumatological credibility of the Church is closely linked to other kinds of arguments found within the framework of fundamental theology, e.g. scriptural, resurrectionist, agapetological, martyrological, praxeological, sperantist, veritative, or the argument from holiness. In all these arguments, the pneumatological aspect must be made even clearer.

Keywords: Holy Spirit; Jesus Christ; Church; credibility of the Church

Kluczowe pytania stawiane przez eklezjologię fundamentalną dotyczą wiarygodności Kościoła, która wiąże się zarówno z jego powstaniem, jak również permanentnym urzeczywistnianiem się w historii. Trzonem uwyraźnienia absolutnej wyjątkowości Eklezji na etapie jej genezy jest udokumentowanie jej boskiego pochodzenia, co wiąże się z wykazaniem, że Jezus z Nazaretu jest prawdziwym Mesjaszem, Synem Bożym oraz że chciał On założyć Kościół i rzeczywiście tego dokonał. To przekonanie pozwala stwierdzić, że zarówno zaistnienie Eklezji, jak i istotne jej elementy, posiadają nie tylko Chrystusową, ale także boską genezę. Niewątpliwie w badaniach 
eklezjologicznych trzeba powracać do genezy Kościoła, aby ją ukazywać w sposób nowy i bardziej zrozumiały dla współczesnego człowieka. Pogłębiona prezentacja wiarygodności Kościoła musi się także odznaczać wrażliwością na współczesne badania chrystologiczne, gdyż one warunkują kompetentne uprawianie eklezjologii.

Drugą płaszczyzną, na której eklezjologia fundamentalna dokonuje uwiarygodnienia Kościoła - po odwołaniu się do jego genezy - jest jego trwanie i permanentne urzeczywistnianie się $\mathrm{w}$ historii. Także $\mathrm{w}$ tym przypadku uwypukla się te elementy, które stanowią o absolutnej wyjątkowości Eklezji. Wykazywanie piękna i osobliwości Kościoła winno się dokonywać zarówno na płaszczyźnie rozumu, jak i wiary - tylko tak możemy poznawać Kościół i jego fenomen, gdyż ma on złożoną strukturę (historyczną i ponadhistoryczną, naturalną i nadprzyrodzoną). Ostatecznie skuteczne pokazanie absolutnej prawdziwości Eklezji uwarunkowane jest zarówno jej właściwym poznaniem i rozumieniem, jak również uwzględnieniem wielorakich sytuacji życia i myślenia osób, do których argumentacja ta jest skierowana.

W niniejszym artykule zostanie podjęte zagadnienie pneumatologicznej wiarygodności Kościoła. Cel ten zostanie zrealizowany na trzech etapach. Na pierwszym etapie zaprezentuje się wydarzenie Pięćdziesiątnicy jako eklezjogenetycznego daru Ducha Świętego. Następnie ukaże się pneumatologiczną ikoniczność Kościoła. Na koniec wyeksplikuje się znaki pneumatologicznej wiarygodności Eklezji.

\section{Pięćdziesiątnica jako eklezjogenetyczny dar Ducha Świętego}

Zagadnienie genezy Kościoła należy do istotnych kwestii eklezjologicznych. Refleksja teologiczna na temat powstania Eklezji jest bogata i wieloaspektowa. Współczesna eklezjologia fundamentalna zagadnienie powstania Kościoła prezentuje integralnie, promując przekonanie, że Jezus Chrystus jest jego Fundatorem, gdyż chciał założyć Kościół i rzeczywiście tego dokonał ${ }^{1}$. Magisterium Ecclesiae naucza, że Eklezja ma swój początek w odwiecznym zamyśle Trójcy Świętej. Eklezja została przygotowana w historii narodu izraelskiego, założona przez Jezusa Chrystusa i objawiona oraz posłana do świata w dniu Pięćdziesiątnicy². Tym samym genezę Kościoła należy wiązać $\mathrm{z}$ całym życiem Jezusa Chrystusa ${ }^{3}$. Jednak definitywnie Eklezja mogła powstać dopiero wtedy, gdy zbawcze dzieło Chrystusa zostało dopełnione przez Jego śmierć i zmartwychwstanie oraz posłanie Ducha Świętego, kiedy „doświadczył swego kon-

1 Bartnik, Kościót, 86; Nagy, Ty jesteś Piotr, 27-68; Piè-Ninot, „Gesù e la Chiesa”, 151-162; Rusecki, Wiarygodność chrześcijaństwa, 238-242; idem, „Boska geneza Kościoła”, 72-78; idem, Traktat o Kościele, 93-108; Seweryniak, Święty Kościół powszedni, 23-42; Napiórkowski, „Geneza, natura i posłanie Kościoła”, 71-105; Góźdź, Kościót zbawienia, 167-168; idem, „Istota Kościoła według Josepha Ratzingera”, 194-196.

$2 \quad K K, 2 ; K K K, 758-759$.

3 Ratzinger, Das neue Volk Gottes, 11. 
kretno-widzialnego narodzenia" ${ }^{4}$. Dlatego wydarzenia paschalne, których finałem jest zesłanie Parakleta, uważa się za właściwy, historyczny początek zbawczej działalności Kościoła ${ }^{5}$.

Odkrywanie i ukazywanie pneumatologicznego wymiaru genezy Kościoła ma długą tradycję w myśli teologicznej. Eklezjologia fundamentalna w genezie Kościoła dostrzega nie tylko obecność posłanego przez Zmartwychwstałego Ducha Świętego, ale także ukazuje Jego eklezjotwórcze działanie ${ }^{6}$. Pięćdziesiątnica jest nazywana „dniem narodzin Kościoła”, „początkiem Kościoła w misji Ducha Świętego”, gdyż Paraklet sprawił, że wspólnota eklezjalna została ukazana światu i do niego posła$\mathrm{na}^{7}$. Według II Soboru Watykańskiego widzialne zesłanie Ducha Świętego jest potwierdzeniem i manifestacją Kościoła, który zrodził się w tajemnicy życia, śmierci i zmartwychwstania Chrystusa ${ }^{8}$. Pięćdziesiątnica staje się dla Kościoła początkiem permanentnej aktualizacji zbawczego dzieła Chrystusa w mocy Ducha Świętego?.

W historii zbawienia zesłanie Ducha Świętego jawi się jako spełnienie obietnicy, którą Jezus dał swoim uczniom: „Ja zaś będę prosił Ojca, a innego Pocieszyciela da wam, aby z wami był na zawsze - Ducha Prawdy" (J 14,16-17). Wcielony Syn Boży w mocy Ducha wypełnia swoje mesjańskie posłannictwo, ale także przez Niego na krzyżu składa Ojcu swoje życie w ofierze $(\mathrm{Hbr} 9,14)^{10}$. Działanie Ducha Bożego w życiu Jezusa znajduje swój definitywny wyraz w Jego zmartwychwstaniu, gdy zostaje On „ustanowiony według Ducha Świętego przez powstanie z martwych pełnym mocy Synem Bożym" (Rz 1,4; por 8,11; 1 Tm 3,16). Duch Ojca nie tylko ożywia ciało Jezusa, ale także dokonuje Jego uwielbienia i wywyższenia ${ }^{11}$. Tym samym działanie Ducha Świętego w historii zbawienia jest ściśle związane z realizacją mesjańskiego posłannictwa Jezusa, a co za tym idzie, z Jego działalnością eklezjotwórczą i realizacją zbawczej misji, którą zmartwychwstały Pan powierzył Kościołowi.

Jan Paweł II w encyklice Dominum et vivificantem naucza, że eklezjotwórcze działania Jezusa, dokonane na krzyżu i w zmartwychwstaniu, zostały dopełnione przez Ducha Świętego jako Parakleta i Ducha Prawdy ${ }^{12}$. Finałem wydarzeń paschal-

\footnotetext{
4 Scheffczyk, Zmartwychwstanie, 262.

5 Witczyk, Kościół Syna Bożego, 231-384; Hryniewicz, Nasza pascha z Chrystusem, 75.

6 Rusecki, „Rola Ducha Świętego w Kościele”, 5-19; idem, Traktat o Objawieniu, 437-439; Hryniewicz, „Pneumatologia a eklezjologia”, 35-58; Nagy, „Duch Święty a tajemnica Kościoła”, 130-135.

7 Ratzinger, Chrystus i Jego Kościól, 100-101.

$8 K K, 4 ; K L, 6$; Mastej, „Paschalna wiarygodność, 140-146.

9 Jan Paweł II, Dominum et vivificantem, nr 25; Skalický, „Fundacyjne wydarzenie chrześcijaństwa”, 27-49; Kudasiewicz, Odkrywanie Ducha Świętego, 248-257.

10 Hryniewicz, Nasza pascha z Chrystusem, 62-63; Czaja, Credo in Spiritum Vivificantem, 104.

11 Hryniewicz, „Dar Zmartwychwstałego”, 214; Rusecki, „Rola Ducha Świętego w Kościele”; Czaja, Credo in Spiritum Vivificantem, 104.

12 Jan Paweł II, Dominum et vivificantem, nr 23.
} 
nych jest posłanie Ducha Świętego do rodzącej się wspólnoty eklezjalnej ${ }^{13}$. Wydarzenie to ukazują Dzieje Apostolskie:

Kiedy nadszedł wreszcie dzień Pięćdziesiątnicy, znajdowali się wszyscy razem na tym samym miejscu. Nagle dał się słyszeć z nieba szum, jakby uderzenie gwałtownego wiatru, i napełnił cały dom, w którym przebywali. Ukazały się im też języki jakby z ognia, które się rozdzieliły, i na każdym z nich spoczął jeden. I wszyscy zostali napełnieni Duchem Świętym, i zaczęli mówić obcymi językami, tak jak im Duch pozwalał mówić (Dz 2,1-4).

Zstąpieniu Parakleta towarzyszą znaki: „szum, jakby uderzenie gwałtownego wiatru”, "języki jakby z ognia” oraz dar umiejętności mówienia obcymi językami. Znaki te odsłaniają dynamizm zbawczej mocy Bożego Ducha oraz potwierdzają prawdziwość Jego zstąpienia na apostołów. Warto też zauważyć, że św. Piotr wyjaśnia zaistniałe wydarzenie jako wypełnienie obietnicy Boga danej przez proroka Joela (Dz 2,16-21). Zdaniem tego apostoła zstąpienie Parakleta potwierdza także faktyczność zmartwychwstania Chrystusa: „Tego właśnie Jezusa wskrzesił Bóg, a my wszyscy jesteśmy tego świadkami. Wyniesiony na prawicę Boga, otrzymał od Ojca obietnicę Ducha Świętego i zesłał Go, jak to sami widzicie i słyszycie" (Dz 2,32-34). Pierwsza Pięćdziesiątnica, czyli objawienie się Ducha Świętego w mocy, stanowi uwiarygodnienie osoby Jezusa Chrystusa, gdyż jest spełnieniem Jego obietnicy oraz ukazaniem zbawczego dzieła, które ostatecznie zrealizowało się przez Jego mękę, śmierć i zmartwychwstanie. Zesłanie Ducha Świętego staje się fundamentem dla wiarygodności Kościoła, który w mocy Bożego Ducha będzie odtąd uobecniał i kontynuował zbawcze dzieło Chrystusa. W tym miejscu warto powrócić do słów Chrystusa, które wypowiedział do uczniów w Wieczerniku: „Pożyteczne jest dla was moje odejście. Bo jeżeli nie odejdę, Pocieszyciel nie przyjdzie do was. A jeżeli odejdę, poślę Go do was” (J 16,7). Zstąpienie Parakleta jest owocem odejścia Jezusa, czyli Jego męki i śmierci. Wydarzenie zesłania Ducha Świętego jest „pożyteczne” dla uczniów i potwierdza Jezusowy zamiar kontynuacji zbawczego dzieła we wspólnocie eklezjalnej przez Parakleta: „[... ] z mojego weźmie i wam da” (J 16,14) ${ }^{14}$. Istotą życia Eklezji jest realizacja zbawczej misji Jezusa, która dokonuje się w mocy Ducha Świętego ${ }^{15}$.

Zgodnie z Chrystusową obietnicą Paraklet przypomina apostołom to, czego Jezus nauczał oraz daje im pełniejsze zrozumienie Jego słów i czynów: „A Pocieszyciel, Duch Święty, którego Ojciec pośle w moim imieniu, On was wszystkiego nauczy i przypomni wam wszystko, co Ja wam powiedziałem" (J 14, 26). Heinrich Schlier wyjaśnia, że

13 Bouyer, Duch Święty Pocieszyciel, 75-80.

14 Jan Paweł II, Dominum et vivificantem, nr 11, 13, 14.

15 Witczyk, Kościót Syna Bożego, 552-554. 
owo „przypominanie” w odniesieniu do Ducha Świętego należy rozumieć trojako: jako uobecnianie, jako odsłanianie i wyjaśnianie, wreszcie jako udostępnianie doświadczenia. Duch, który jest Duchem Ojca i Duchem Jezusa, uobecnia osobę i dzieło Jezusa do tego stopnia, że człowiek wchodzi w samą głębię Jego prawdy ${ }^{16}$.

Duch Święty zapewnia zatem ciągłość i tożsamość Chrystusowego orędzia wśród zmieniających się warunków i okoliczności jego proklamacji. Dzięki Parakletowi przepowiadane we wspólnocie eklezjalnej słowo Boże jest wiąż żywe i skuteczne.

Także skierowane do uczniów polecenie zmartwychwstałego Pana: „Weźmijcie Ducha Świętego! Którym odpuścicie grzechy, są im odpuszczone, a którym zatrzymacie, są im zatrzymane” (J 20,22-23), uwyraźnia miejsce Bożego Ducha w eklezjalnej misji uświęcania. Duch Święty jest dla wierzących Źródłem nowego życia i świętości. Realizacja przez Kościół misji uświęcania dokonuje się w mocy Ducha Świętego szczególnie przez sakramentalną posługę Kościoła. Permanentna realizacja posługi sakramentalnej oraz jej zbawcza skuteczność stanowią o wiarygodności Eklezji ${ }^{17}$.

\section{Pneumatologiczna ikoniczność Kościoła}

Napełnienie Kościoła obecnością Ducha Świętego nie jest wydarzeniem jednorazowym (por. Dz 4,31; 8,17; 10,44-48), ale trwałym osobowym Darem ${ }^{18}$. Tajemnica Zielonych Świąt dokonuje się nieustannie, zarówno w życiu całego Kościoła, jak również poszczególnych wiernych, których Duch namaszcza, uświęca i wprowadza we wspólnotę eklezjalną. Celem tej części artykułu jest próba ukazania misterium obecności Ducha Świętego w Kościele przez odwołanie się do kategorii ikony.

W ogólnym teologicznym rozumieniu ikona otwiera na nową, nadprzyrodzoną, Boską rzeczywistość, jest oknem pozwalającym zbliżyć się do Transcendencji ${ }^{19}$. W naszym pojmowaniu chcemy poszerzyć rozumienie ikony, gdyż ona nie tylko otwiera, prowadzi, ale także uobecnia rzeczywistość, na którą wskazuje, co więcej, wyraża ją, choć jej nie zamyka w sobie i nie ogranicza. Ikona ma teofanijny charakter, gdyż jest „miejscem” objawienia się Boga, jest przestrzenią spotkania Boga z człowiekiem, „rzeczywistości ziemskiej z wiecznością”. Dlatego za Marianem Ruseckim możemy stwierdzić, że „najgłębszy sens ikony tkwi w jej personalistycznym rozumieniu” oraz że z ikoną związana jest „łaska, światło i chwała Boża”, czyli osobowa obecność Boga ${ }^{20}$.

\footnotetext{
16 Schlier, „Główne zręby nowotestamentowej teologii”, 113; por. Rusecki, „Rola Ducha Świętego w Kościele”, 13-14.

17 Mastej, Staurologiczno-rezurekcyjna wiarygodność, 285-295.

18 Czaja, „Ku nowej formule dogmatycznej”, 280-281.

19 Stachowicz, „Ikona a ontologia”, 10-11.

20 Rusecki, „Próba określenia przedmiotu ikonicznej teologii fundamentalnej”, 33.
} 
Używając określenia „pneumatologiczna ikoniczność Kościoła”, chcemy uwyraźnić prawdę, że życie Kościoła ma swoje źródło w Osobie Ducha Świętego, który jest Niewidzialnym Bogiem. Duch Święty - jak uczy II Sobór Watykański, odwołując się do tradycji patrystycznej - mieszka w Kościele, jest jego „sercem” i „duszą”, choć Kościół Go nie ogranicza ${ }^{21}$. Tak jak ikona odsłania nową, nadprzyrodzoną, boską rzeczywistość i wprowadza w nią człowieka, tak Kościół, ożywiany permanentnie przez Ducha Świętego, daje człowiekowi możliwość wejścia w misterium Trójjedynego Boga: Ojca, Syna i Ducha Świętego. Tak jak ikona ukazuje i urzeczywistnia Bożą obecność, tak Kościół przez zbawczy dynamizm odsłania oblicze Ducha Świętego i wprowadza wierzących w osobową relację z Bogiem.

Ponieważ w krótkim artykule nie jest możliwe całościowe ukazanie pneumatologicznej ikoniczności Kościoła, dlatego ograniczymy się do jej prezentacji przez odwołanie się do dwu znamion Eklezji - jedności i świętości.

Ważnym elementem w ukazaniu pneumatologicznej ikoniczności Kościoła, a zarazem jednym $\mathrm{z}$ jego istotnych przymiotów, jest jedność, która wyraża się w ścisłym związku wiernych z Bogiem oraz wiernych między sobąą ${ }^{22}$ Jedność Kościoła ma swoje źródło w Duchu Świętym oraz uwyraźnia Jego oblicze. Pneumatologiczna jedność Kościoła uwidacznia się w budowaniu eklezjalnej wspólnoty. Już w dniu Zielonych Świąt Paraklet zstąpił na wieczernikową wspólnotę, która Jego mocą została w pełni ukonstytuowana i posłana do świata. Eklezja wierzących w Chrystusa, która została zjednoczona, ożywiona i umocniona przez Ducha, stanowi bosko-ludzką komunię i ma dynamiczny charakter. Mocą Ducha nieustannie rodzi się w nowych członkach przez wiarę i chrzest święty, staje się, rozwija i wzrasta (zarówno w sensie „ilościowym”, jak i „jakościowym” ${ }^{23}$. Eklezjologia posoborowa eksponuje współistnienie w Kościele jedności i różnorodności ${ }^{24}$. Duch Święty sprawia jedność w wielości członków, różnorodności darów, funkcji i posług w Kościele. On jednoczy ludzi wszystkich narodów, ras, kultur, języków i różnorodnych form życia. Im jedność wierzących z Bogiem oraz między nimi jest mocniejsza, im głębsze zjednoczenie, tym wyraźniejsza jest wiarygodność Kościoła. Jeśli jedność jest osłabiona lub niszczona przez grzech, wówczas znak wiarygodności staje się mało czytelny. Wszelkie podziały Kościoła osłabiają jego wiarygodność i stają się zgorszeniem ${ }^{25}$. Widzialną więzią jedności Eklezji są apostołowie i ich następcy w jedności z papieżem, podczas gdy więź niewidzialną zapewnia Duch Święty ${ }^{26}$.

\footnotetext{
21 KK, 4, por. Jan Paweł II, Dominum et vivificantem, $\mathrm{nr} 25$.

22 Mastej, „Jedność i jedyność jako znak wiarygodności Kościoła”, 139-155.

23 Rusecki, „Rola Ducha Świętego w Kościele”, 13.

24 Czaja, Credo in Spiritum Vivificantem, 202; por. Napiórkowski, „Modele jedności”, 479-503.

25 Rusecki - Kaucha - Pietrzak, „Znaki wiarygodności Kościoła”, 1383; Rusecki, „Czy Kościół w Polsce jest wiarygodny?”, 150; idem, „Wiarygodność Kościoła w Polsce”, 385. 
Na drodze jedności Duch Święty wyposaża Kościół w dary hierarchiczne i charyzmatyczne. Z woli Chrystusa istnieje w Kościele powołanie i posłanie apostolskie, które ma swoją genezę w wyborze i ustanowieniu kolegium Dwunastu z Piotrem na czele. Apostołom, którzy zostali obdarowani przez Mistrza szczególnym darem Ducha Świętego, została zlecona posługa nauczania, uświęcania i pasterzowania. Również konstytuowanie się struktur hierarchicznych w pierwotnym Kościele dokonuje się przy udziale Ducha Świętego i służy rozwojowi wspólnoty ${ }^{27}$.

Budowanie Kościoła przez Ducha dokonuje się także przez obdarowywanie wiernych bogactwem darów, stosownie do potrzeb wspólnoty ${ }^{28}$. Chodzi zwłaszcza o charyzmaty, których Duch udziela poszczególnym wiernym dla dobra całej wspólnoty: „Wszystkim zaś objawia się Duch dla [wspólnego] dobra” (1 Kor 12,7). Ich przeznaczenie jest wspólnototwórcze, gdyż służą dobru całego Kościoła, zarówno w jego genezie, jak i w trwaniu. Wielość darów charyzmatycznych nie zagraża jedności communio fidelium, gdyż pochodzą od Ducha Jedności ${ }^{29}$. Paraklet sprawia, że wszelkie posługiwanie w Kościele ma charakter charyzmatyczny, bowiem kapłaństwo hierarchiczne stanowi kontynuację charyzmatu apostolskiego. Nowy Testament ukazuje rolę Ducha Świętego w wyborze konkretnych osób do posługiwania w Kościele (Dz 13,13; $1 \mathrm{Tm}$ 1,18); wskazuje też na charyzmat udzielany tym osobom przez włożenie rąk apostołów lub prezbiterów (1 Tm 4,14; 2 Tm 1,6). Tym samym Duch Święty słusznie jest nazywany Współtwórcą eklezjalnej komunii ${ }^{30}$.

Drugim elementem w ukazywaniu pneumatologicznej ikoniczności Kościoła, a zarazem istotnym Jego przymiotem, jest świętość. Sprawcą świętości Eklezji jest Duch Święty, a jej codzienna świętość jest obliczem Bożego Ducha ${ }^{31}$. Kościół jest święty, choć stale się uświęca; nieustannie potrzebuje uświęcającej mocy i oczyszczającego ognia Bożego Ducha. Widoczna w życiu Kościoła świętość jest obliczem - ikoną - Bożego Ducha, który jest Źródłem świętości i wszelkiego uświęcenia.

Świętość Kościoła ma wymiar ontologiczny, który należy do istoty Kościoła, oraz egzystencjalny, który wyraża się w życiu wierzących ${ }^{32}$; jest owocem i darem łaski Ducha Świętego, który uzdalnia człowieka do życia Ewangelią. Chrześcijanin zostaje uświęcony przez Ducha już w sakramencie chrztu świętego. Dar ten powinien on jednak rozwijać przez współpracę z Bożą łaską. Dążenie do osiągnięcia pełnej świętości staje się życiowym zadaniem, które może zostać wykonane jedynie na drodze współpracy człowieka z Duchem Świętym ${ }^{33}$. Paraklet jest bowiem żarem Bożej mi-

\footnotetext{
27 Międzynarodowa Komisja Teologiczna, „Apostolskość Kościoła i sukcesja apostolska”, 24; Pié-Ninot, Wprowadzenie do eklezjologii, 86-87.

$28 K K, 12$.

29 Kudasiewicz, „Odkrywanie Ducha Świętego”, 338-352; Czaja, Credo in Spiritum Vivificantem, 216-222.

30 Mastej, Staurologiczno-rezurekcyjna wiarygodność, 268-271.

31 Krasiński, „Świętość Kościoła”, 1214.

32 Ledwoń, „Świętość jako motyw wiarygodności”, 1209-1213; Krasiński, „Świętość Kościoła”, 1213-1216.

33 Chmiel, „Powszechne powołanie do”, 270-271.
} 
łości - rozpala i uzdalnia serca wierzących do życia w świętości. Duch uświęca wierzących Bożą mocą, daje im i rozwija w nich życie Boże oraz doprowadza do pełni zjednoczenia z Bogiem ${ }^{34}$. Uświęcony przez Ducha Świętego, Kościół sam dokonuje uświęcenia. Staje się Kościołem uświęcającym oraz Kościołem uświęconych, czyli tych, którzy stają się święci ${ }^{35}$.

$\mathrm{Na}$ drodze do świętości niekiedy pojawia się grzech. Wiarygodność Kościoła uwidacznia się w trosce o każdego człowieka, dlatego potępia on grzech, lecz nie odrzuca grzesznika. Przekonanie o własnej grzeszności jest warunkiem trwania w prawdzie, zgodnie z nauką Apostoła: „Jeśli mówimy, że nie mamy grzechu, to samych siebie oszukujemy i nie ma w nas prawdy" (1 J 1,8). Moralna niedoskonałość członków Eklezji sprawia, że jego oblicze nie jaśnieje jeszcze pełnym blaskiem świętości. Wiarygodność Kościoła wzrasta, gdy miłością przebaczającą i uświęcającą obdarza on w sakramencie pokuty tych, którzy wyznają swoje grzechy. W tym miejscu warto przywołać wskazane przez Chrystusa posłannictwo Ducha Świętego: „On zaś, gdy przyjdzie, przekona świat o grzechu, o sprawiedliwości i o sądzie” (J 16,8) ${ }^{36}$. Tę misję Duch Święty nieustannie realizuje w Kościele. Grzech wierzących przysłania oblicze Ducha Świętego, które zawsze jaśnieje świętością we wspólnocie eklezjalnej.

Jak już zauważono, omówienie dwu istotnych przymiotów Eklezji - jedności i świętości - nie wyczerpuje zagadnienia pneumatologicznej ikoniczności Kościoła. Stanowi jedynie aspektowe uwyraźnienie - przez odwołanie się do kategorii ikony obecności i działania Ducha Świętego w Kościele. Dopowiedzieć trzeba, że pneumatologiczna ikoniczność Eklezji widoczna jest także w przepowiadaniu słowa Bożego oraz w sakramentach Kościoła ${ }^{37}$, co zostało jedynie zasygnalizowane, ale może się stać przedmiotem odrębnego opracowania.

\section{Znaki pneumatologicznej wiarygodności Eklezji}

Po przedstawieniu Pięćdziesiątnicy jako eklezjogenetycznego daru Ducha Świętego oraz ontologicznego wymiaru pneumatologicznej ikoniczności Kościoła, czas na wyeksplikowanie znaków pneumatologicznej wiarygodności Kościoła. Ich dostrzeżenie

\footnotetext{
34 Brudz, „Misterium Kościoła”, 60-61.

35 de Lubac, Medytacje o Kościele, 92; Mastej, Staurologiczno-rezurekcyjna wiarygodność, 274-275.

36 Eklezjologiczne znaczenie tej zapowiedzi Jezusa, odnośnie do roli Ducha Ŝ́więtego, który przekonuje świat o grzechu przedstawia Jan Paweł II w drugim rozdziale encykliki Dominum et vivificantem.

37 „[... w wajemnicy sakramentów ujawnia się dzieło Chrystusa aktualizowane przez Ducha. On podczas ich sprawowania przychodzi i powoduje w przyjmujących je skutki nadprzyrodzone. Sakramenty św. oznaczają łaskę i jej udzielają. Kościół jest ich widzialnym szafarzem, a Duch niewidzialnym dawcą życia” (Rusecki, „Rola Ducha Świętego w Kościele”, 15).
} 
możliwe jest na płaszczyźnie postrzegania zmysłowego, jednak ich pełne rozpoznanie może się dokonać przy jednoczesnym udziale ratio i fides.

Do znaków, które mogą stanowić podstawę do zbudowania pneumatologicznej wiarygodności Eklezji należy zaliczyć:

- Wyznawanie przez Kościół wiary w Ducha Świętego. Żywa wiara Kościoła w Ducha Świętego, który jest jedną z Osób Bożych Trójcy Świętej, może stanowić punkt wyjścia w wykazaniu pneumatologicznej wiarygodności Kościoła.

- Uznawanie misji i działania Ducha Świętego w historii zbawienia oraz w życiu Eklezji. Kościół nie może bowiem zapomnieć o działaniu Bożego Ducha od początku świata oraz o żywej i osobowej obecności Parakleta w Kościele. Eklezja wiarygodna żyje w przekonaniu, że Duch Święty jest Jej duszą - Panem i Ożywicielem.

- Kościół permanentnie wiarygodny naucza o Duchu Świętym. Aspekty pneumatologii winny być stale obecne w przepowiadaniu, zwłaszcza homilijnym i katechetycznym. Nauczanie Kościoła ma być ukierunkowane nie tylko chrystologicznie czy eklezjologicznie, ale także pneumatologicznie.

- Pneumatologiczna wiarygodność Eklezji wyraża się w permanentnej modlitwie o zesłanie Ducha Świętego. „Najbardziej rozwiniętą postać przybiera epikleza w liturgii eucharystycznej jako prośba zgromadzonych («my») do Ojca, aby zesłał Ducha Świętego na nas i na złożone dary chleba i wina. Najpierw na nas, abyśmy przemienieni i oczyszczeni, zdolni byli dzięki Duchowi rozpoznać przez wiarę życiodajną moc świętych postaci przemienionych Jego mocą w Ciało i Krew Chrystusa. Epikleza jest modlitewnym zastosowaniem całej teologii Ducha Świętego" ${ }^{\text {"38 }}$. Warto uwypuklić piękno epiklezy Kościoła, który przyzywa Ducha Świętego w ważnych chwilach jego życia i misji, np. w czasie liturgii święceń kapłańskich czy sakramentu małżeństwa.

- Wiarygodność Eklezji uwidacznia się przez pokorne jej trwanie w postawie przyzywania Ducha Świętego, gdyż Kościół może jedynie prosić Ducha Świętego o Jego dary, a nie może „rozporządzać” Duchem Świętym i decydować „za Niego" ${ }^{\prime 39}$.

- O pneumatologicznej wiarygodności Kościoła stanowi także indywidualna modlitwa wiernych do Ducha Świętego. Warto uwrażliwiać wiernych na możliwość i potrzebę epiklezy w życiu codziennym. Podobnie jak przepięknie rozwinęła się w Kościele w Polsce pobożność maryjna i kult świętych, tak należy zadbać o pogłębienie pobożności pneumatologicznej ${ }^{40}$.

\footnotetext{
38 Hryniewicz, „Dar Zmartwychwstałego”, 219.

39 Hryniewicz, „Dar Zmartwychwstałego”, 219.

40 Na uwagę zasługuje praca zbiorowa po redakcją K. Guzowskiego i G. Bartha pt. Duch Święty w naszej codzienności.
} 
- Ważnym elementem w wykazaniu pneumatologicznej wiarygodności Kościoła jest pokazanie jego faktycznej otwartości na działania Ducha Świętego we wszystkich wymiarach misji i posługi eklezjalnej, a zwłaszcza kapłańskiej, nauczycielskiej i pasterskiej. Szczególnie ważne jest otwarcie na działanie Ducha Świętego osób sprawujących posługę władzy w Kościele, szczególnie przy powoływaniu do posług i zadań eklezjalnych.

- Pneumatologiczna wiarygodność Kościoła uwidacznia się poprzez kompetentne i trafne rozpoznawanie tego, co pochodzi od Ducha Bożego oraz tego, co od Niego nie pochodzi. Istotnym problem Kościoła katolickiego w Polsce jest przenikanie do niego protestanckiej duchowości i religijności charyzmatyczno-pentekostalnej ${ }^{41}$. Zadaniem biskupów diecezjalnych jest trafne rozeznawanie i ostrzeganie wiernych przed praktykami pseudocharyzmatycznymi, które mogą się pojawić w Kościołach lokalnych.

- Z powyższego znaku wynika kolejny. Można go określić jako wrażliwość i otwartość Eklezji na natchnienia Ducha Świętego, który - w co wierzymy - mówi zarówno do Kościoła powszechnego, jak również do Kościołów partykularnych i poszczególnych wiernych. Wsłuchanie się w głos Parakleta pozwala Kościołowi rozpoznać i właściwie zinterpretować znaki czasu, co czyni go wiarygodnym w oczach świata ${ }^{42}$.

- Odwaga wierzących w dawaniu świadectwa, które dokonuje się w mocy Ducha Świętego, to kolejny znak pneumatologicznej wiarygodności Eklezji. O prawdziwości i wyjątkowości Kościoła świadczą zarówno męczennicy, którzy oddali życie dla Chrystusa, jak również chrześcijanie, którzy w codziennym życiu, przez modlitwę, pracę i miłość do każdego człowieka, składają wobec świata świadectwo wiary. Wciąż aktualne pozostaje zapewnienie skierowane do apostołów przez Zmartwychwstałego: „gdy Duch Święty zstąpi na was, otrzymacie Jego moc i będziecie moimi świadkami w Jerozolimie i w całej Judei, i w Samarii, i aż po krańce ziemi" (Dz 1,8).

- Wiarygodność pneumatologiczna Eklezji jest ściśle związana ze świętością, która jest owocem Ducha Świętego, o czym była już mowa wcześniej. Źródłem świętości wspólnoty kościelnej jest obecność w niej Chrystusa oraz Jego Ducha w każdym czasie i w każdym miejscu. Świętość życia jest owocem współpracy chrześcijanina z Bożym Duchem. Święci stanowią dla wierzących wzór życia oraz potwierdzenie prawdy, że życie Ewangelią na co dzień jest możliwe.

- Pneumatologiczna wiarygodność Kościoła uwidacznia się przez doświadczenie działania Ducha Świętego w życiu wiernych. Zdaniem Wacława Hryniewicza „Doświadczenie Ducha Świętego jest nade wszystko doświadczeniem sakramen-

41 Kobyliński, „Hybrydowa inwazja”, 75-97.

42 Karwacki, „Od chrystomonizmu ku pneumatologicznej teologii”, 131. 
talnym. Sama celebracja liturgii eucharystycznej jawi się w tej perspektywie jako wielkie przeżycie charyzmatyczne, będące źródłem różnorakich darów Ducha"43.

- Także widoczne w życiu wiernych dary Ducha Świętego: mądrości, rozumu, rady, męstwa, umiejętności, pobożności, bojaźni Bożej - stanowią o pneumatologicznej wiarygodności Kościoła. Przykładowo warto przyjrzeć się, jak te dary kształtują życie oraz wiarę osób, które przyjęły sakrament bierzmowania. Kościół w Polsce winien zmierzyć się z odpowiedzią na powyższe pytanie, gdyż niepokojącym zjawiskiem jest rezygnacja przez ludzi młodych z udziału w niedzielnej Mszy św. czy życia sakramentalnego. Właściwa diagnoza oraz skuteczne rozwiązanie tego problemu może także stanowić przesłankę w wykazaniu wiarygodności Kościoła.

- Na pneumatologiczną wiarygodność Kościoła wskazują widoczne w życiu wiernych owoce Ducha Świętego. Katechizm Kościoła Katolickiego naucza: „Tradycja Kościoła wymienia ich dwanaście: «miłość, wesele, pokój, cierpliwość, uprzejmość, dobroć, wspaniałomyślność, łaskawość, wierność, skromność, wstrzemięźliwość, czystość»" (Ga 5,22-23) ${ }^{44}$. Znakiem rozpoznawczym w życiu wspólnoty eklezjalnej oraz poszczególnych wiernych są owoce Ducha. Kościół Chrystusowy rozpoznajemy po owocach.

- Jako ostatni element na drodze ukazywania pneumatologicznej wiarygodności należy podkreślić, że Kościół Chrystusowy powinien żyć w przekonaniu, że „W razie potrzeby sam Duch Święty wzbudzi «proroków» i «wyznawców», którzy pomogą Kościołowi zachować tożsamość Ewangelii”" ${ }^{35}$. Zaufanie Kościoła i zdanie się na Bożego Ducha wzmacnia jego wiarygodność. Natomiast pokładanie przez Kościół nadziei w tym świecie, a szczególnie w dobrach materialnych, ją osłabia.

Wskazane znaki stanowią o wiarygodności Kościoła. Ich szczegółowe rozpoznanie i opisanie jest ważnym etapem w wykazaniu jego pneumatologicznej wiarygodności. Wnikliwa analiza powyższych znaków może inspirować do wskazania nowych. Warto w tym miejscu dodać, że zastosowana w punkcje trzecim kategoria znaku koresponduje $\mathrm{z}$ wprowadzonym w punkcje drugim pojęciem ikony. Wydaje się jednak, że o ile mówienie o pneumatologicznej ikoniczności Kościoła w odniesieniu do jego ontologicznego wymiaru jest w pełni uzasadnione, o tyle odniesienie pneumatologicznej ikoniczności do egzystencjalnego wymiaru życia Kościoła domaga się dalszych pogłębionych badań. Dlatego w tym przypadku posłużono się powszechnie stosowaną w teologii fundamentalnej kategorią znaku.

\footnotetext{
43 Hryniewicz, „Dar Zmartwychwstałego”, 218-219.

$44 \quad$ KKK, 1832.

45 Hryniewicz, „Dar Zmartwychwstałego”, 218.
} 


\section{Zakończenie}

Teologia fundamentalna stawia sobie za cel ukazanie racjonalnych podstaw wiary. Czyni to przez budowanie argumentów za wiarygodnością chrześcijaństwa i Kościoła. Celem niniejszego opracowania było ukazanie pneumatologicznej wiarygodności Kościoła. Holistyczna prezentacja obecności i działania Ducha Świętego w Kościele - zarówno w jego genezie, jak również w permanentnym urzeczywistnianiu się w historii w wymiarze ontologicznym i egzystencjalnym - stanowi podstawę do wykazania jego absolutnej wyjątkowości, co jest możliwe przy równoczesnym udziale ratio i fides. Pneumatologiczna wiarygodność Kościoła jest powiązana z innymi argumentami za wiarygodnością chrześcijaństwa i Kościoła, np. skrypturystycznym, rezurekcjonistyczny, agapetologicznym, martyrologicznym, prakesologicznym, sperancyjnym, werytatywnym czy ze świętości. W argumentach tych trzeba jeszcze mocniej uwyraźniać aspekt pneumatologiczny.

\section{Bibliografia}

Bartnik, C.S., Kościół (Lublin: Wydawnictwo KUL 2009).

Bouyer, L., Duch Święty Pocieszyciel. Duch Święty i życie w łasce (Kraków: Wydawnictwo M 1998).

Brudz, J., „Misterium Kościoła”, Idee przewodnie soborowej Konstytucji o Kościele (red. S. Grzybek) (Kraków: Polskie Towarzystwo Teologiczne 1971) 45-62.

Chmiel, J., „Powszechne powołanie do świętość w Kościele”, Idee przewodnie soborowej Konstytucji o Kościele (red. S. Grzybek) (Kraków: Polskie Towarzystwo Teologiczne 1971) 267-284.

Czaja, A., Credo in Spiritum Vivificantem. Pneumatologiczna interpretacja Kościoła jako komunii w posoborowej teologii niemieckiej (Lublin: Wydawnictwo KUL 2003).

Czaja, A., „Ku nowej formule dogmatycznej: jedna osoba w wielu osobach”, Duch, który jednoczy. Zarys pneumatologii (red. M. Marczewski) (Lublin: Polihymnia 1998) 259-293.

Góźdź, K., „Istota Kościoła według Josepha Ratzingera”, Teologia fundamentalna w twórczości Josepha Ratzingera (red. K. Kaucha - J. Mastej) (Lublin: Wydawnictwo KUL 2017) 191-201.

Góźdź, K., Kościół zbawienia (Lublin: Wydawnictwo KUL 2010).

Guzowski, K. - Barth, G., (red.), Duch Święty w naszej codzienności (Lublin: Gaudium 2010).

Hryniewicz, W., „Dar Zmartwychwstałego. Pneumatologia prawosławna i jej znaczenie dla ekumenie", Duch, który jednoczy. Zarys pneumatologii (red. M. Marczewski) (Lublin: Polihymnia 1998) 211-232.

Hryniewicz, W., Nasza pascha z Chrystusem (Zarys Chrześcijańskiej Teologii Paschalnej 2; Lublin: TN KUL 1987).

Hryniewicz, W., „Pneumatologia a eklezjologia”, Collectanea Theologica 47/2 (1977) 33-58.

Jan Paweł II, Encyklika „Dominum et vivificantem” (1986). 
Karwacki, R., „Od chrystomonizmu ku pneumatologicznej teologii”, Duch, który jednoczy. Zarys pneumatologii (red. M. Marczewski) (Lublin: Polihymnia 1998) 119-156.

Katechizm Kościoła Katolickiego (Poznań 1994) (= KKK).

Kobyliński, A., „Hybrydowa inwazja. Podmiana pobożności - katolickiej na zielonoświątkową”, Alarm dla Kościoła. Nowa reformacja? (red. P. Milcarek - T. Rowiński) (Warszawa: Demart 2019) 75-97.

Krasiński, J., „Świętość Kościoła”, Leksykon teologii fundamentalnej (red. M. Rusecki et al.) (Lublin - Kraków: Wydawnictwo M 2002) 1213-1217.

Kudasiewicz, J., Odkrywanie Ducha Świętego (Kielce: Jedność 1998).

Ledwoń, I.S., „Świętość jako motyw wiarygodności), Leksykon teologii fundamentalnej (red. M. Rusecki et al.) (Lublin - Kraków: Wydawnictwo M 2002) 1208-1213.

de Lubac, H., Medytacje o Kościele (Kraków: WAM 1997).

Mastej, J., „Jedność i jedyność jako znak wiarygodności Kościoła”, Reformatorzy a Kościół rzymski (red. A.A. Napiórkowski) (Kraków: Wydawnictwo Naukowe UPJPII 2017) 139-155.

Mastej, J., „Paschalna wiarygodność chrześcijaństwa i Kościoła według Josepha Ratzingera/ Benedykta XVI", Teologia fundamentalna w twórczości Josepha Ratzingera (red. K. Kaucha - J. Mastej) (Lublin: Wydawnictwo KUL 2017) 135-151.

Mastej, J., Staurologiczno-rezurekcyjna wiarygodność chrześcijaństwa (Lublin: Wydawnictwo KUL 2014).

Międzynarodowa Komisja Teologiczna, „Apostolskość Kościoła i sukcesja apostolska”, Od wiary do teologii. Dokumenty Międzynarodowej Komisji Teologicznej (red. J. Królikowski) (Kraków: Wydawnictwo Księży Sercanów 2000) 19-31.

Nagy, S., „Duch Święty a tajemnica Kościoła”, Jan Paweł II. Dominum et vivificantem. Tekst $i$ komentarze (red. A.L. Szafrański) (Lublin: Wydawnictwo KUL 1994) 119-135.

Nagy, S., Ty jesteś Piotr, czyli Skała i na tej Skale zbuduję Kościót mój. Studium o widzialnym Kościele (Biblioteka „Niedzieli” 234; Częstochowa: Kuria Metropolitalna w Częstochowie - Tygodnik Katolicki „Niedziela” 2009).

Napiórkowski, A.A., „Geneza, natura i posłanie Kościoła”, Kościół Chrystusowy (red. T. Dzidek et al.) (Teologia fundamentalna 4; Kraków: Wydawnictwo Naukowe Papieskiej Akademii Teologicznej 2003) 71-105.

Napiórkowski, S.C., „Modele jedności”, Ku chrześcijaństwu jutra. Wprowadzenie do ekumenizmu (red. W. Hryniewicz - J.S. Gajek - S.J. Koza) (Lublin: Wydawnictwo KUL 1996) 479-503.

Piè-Ninot, S., „Gesù e la Chiesa”, Dizionario di teologia fondamentale (red. R. Latourelle - R. Fisichella) (Assimi: Cittadella 1990) 151-162.

Pié-Ninot, S., Wprowadzenie do eklezjologii (Kraków: WAM 2002).

Ratzinger, J., Chrystus i Jego Kościół, wyd. 2 (Kraków: eSPe 2005).

Ratzinger, J., Das neue Volk Gottes. Entwürfe zur Ekklesiologie (Düsseldorf: Patmos 1977).

Rusecki, M., „Boska geneza Kościoła”, Kościół w czasach Jana Pawła II (red. M. Rusecki K. Kaucha - J. Mastej) (Lublin: Wydawnictwo KUL - Gaudium 2005) 65-78.

Rusecki, M., „Czy Kościół w Polsce jest wiarygodny?”, Wiarygodność Kościoła wobec przemian w Polsce. Quo vadis Ecclesia Polonorum? (red. M. Rusecki) (Pelplin - Lublin: Bernardinum 1994) 143-156. 
Rusecki, M., „Próba określenia przedmiotu ikonicznej teologii fundamentalnej”, Wokó teologii ikony (red. B. Kochaniewicz) (Studia Theologiae Fundamentalis 2; Poznań: Redakcja Wydawnictw UAM. WT 2011) 31-46.

Rusecki, M., „Rola Ducha Świętego w Kościele według encykliki Dominum et vivificantem Jana Pawła II", Roczniki Teologiczne 45/2 (1998) 5-19.

Rusecki, M., „Wiarygodność Kościoła w Polsce jako rzeczywistości personalistycznej i dynamicznej”, Studia Warmińskie 30 (1993) 377-390.

Rusecki, M., Traktat o Kościele (Lublin: Wydawnictwo KUL 2014).

Rusecki, M., Traktat o Objawieniu (Kraków: Wydawnictwo Księży Sercanów 2007).

Rusecki, M., Wiarygodność chrześcijaństwa. I. Z teorii teologii fundamentalnej (Lublin: TN KUL 1994).

Rusecki, M. - Kaucha, K. - Pietrzak, A., „Znaki wiarygodności Kościoła”, Leksykon teologii fundamentalnej (red. M. Rusecki et al.) (Lublin - Kraków: Wydawnictwo M 2002) 1381-1393.

Scheffczyk, L., Zmartwychwstanie (Warszawa: Instytut Wydawniczy PAX 1984).

Schlier, H., „Główne zręby nowotestamentowej teologii słowa Bożego”, Concilium 4/1-10 (1968) 112-118.

Seweryniak, H., Święty Kościót powszedni (Warszawa: Biblioteka „Więzi” 1996).

Skalický, K., „Fundacyjne wydarzenie chrześcijaństwa. Ukrzyżowanie i zmartwychwstanie Jezusa z Nazaretu", Chrześcijaństwo jutra (red. M. Rusecki et al.) (Lublin: TN KUL 2001) 27-49.

Sobór Watykański II, Konstytucja dogmatyczna o Kościele Lumen gentium (1964) (= KK).

Sobór Watykański II, Konstytucja o liturgii świętej „Sacrosanctum Concilium” (1963) (= KL).

Stachowicz, K., „Ikona a ontologia”, Wokół teologii ikony (red. B. Kochaniewicz) (Studia Theologiae Fundamentalis 2; Poznań: Redakcja Wydawnictw UAM. WT 2011) 9-19.

Witczyk, H., Kościół Syna Bożego. Studium eklezjologii Czwartej Ewangelii (Biblioteka „Verbum Vitae” 3; Kielce: Instytut Teologii Biblijnej „Verbum” 2012). 